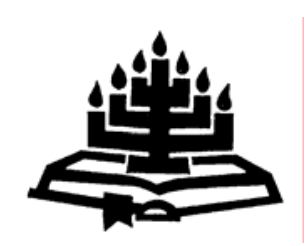

\title{
Respons op J.H. van Wyk se Reformasie en onderwys(-ers): enkele teologiese perspektiewe
}

\author{
P.J. Strauss
}

Fakulteit Teologie

Universiteit van die Vrystaat

BLOEMFONTEIN

E-pos: straussp.hum@mail.uovs.ac.za

\section{Inleidend}

In hierdie respons gaan dit om "teologiese perspektiewe" op die reformasie van die onderwys. Dit gaan dus nie om die respons van 'n onderwysspesialis per se nie. Ek "staan" openlik in die reformatoriese tradisie waarvoor Van Wyk pleit.

Die rede vir my respons is ook my belangstelling en betrokkenheid in buiteskoolse jeugbedrywighede soos Die Voortrekkers. Die uitgesproke ABC-karakter van Die Voortrekkers bevat 'n saak waarna Van Wyk in sy verduideliking van Christelik-nasionaal verwys, naamlik 'n omvattende of konsekwente Christelike benadering of beskouing (die groot $\mathrm{C}$ ) wat jou kulturele idioom (die groot $A$ ) en die rigting en inhoud van jou burgerskap bepaal (die groot B). Hoewel Die Voortrekkers primêr 'n kulturele jeugbeweging is, wil dit volgens sy literatuur alles konsekwent Christelik aanpak. Dit gaan hier dus ook om 'n koninkryksbenadering waarin alles - ek gebruik graag Van Wyk se terme - deurgaans "op die eer van God as Koning" gerig moet wees.

Van Wyk spreek hom tereg uit teen die uitdrukking "Christelik en nasionaal", so asof dit twee aparte en selfstandige groothede is wat in spanning naas mekaar bestaan. ${ }^{1}$ In die amptelike benadering van

$1 \quad$ Vergelyk 'n kritiese bespreking van die Afrikaner se tradisionele opvatting van Christelik-nasionaal by Botha (1982). Hierteenoor is 'n positiewe, prinsipiële uiteensetting van die saak deur Strauss (1969:14 e.v.). 
Die Voortrekkers het die A en die B slegs plek as dit in terme van 'n lewensomvattende $\mathrm{C}$ grondig gereformeer is. Anders gestel, dit gaan by Die Voortrekkers in hulle grondwet, amptelike literatuur en beleid, in hulle amptelike benadering - soos by Van Wyk - primêr om die C. Die C wat moet grondvat of "inheems word", wat gestalte kry in die uitlewing van die A en die B. Ek sê "amptelik", omdat hierdie jeugbeweging uit sondige mense bestaan en daarom natuurlik nie altyd in alles getrou aan die $C$ is nie.

Dit bring my by 'n prinsipiële denkfout wat in die tema van Van Wyk sigbaar word, naamlik dat dit hier gaan om teologiese perspektiewe. So asof Bybelse uitgangspunte vir die onderwys of 'n koninkryksvisie in die onderwys as 'n nie-kerklike terrein van die lewe - Van Wyk se eie oortuiging - noodwendig teologies van aard is. Vanuit 'n konsekwente koninkryksperspektief het ons hier natuurlik met algemene Christelike waarhede te doen wat nie net seksioneel teologies van aard is of die teologiese aspek "verteenwoordig" nie. Gereformeerde Teologie en die Christelike of Reformatoriese Wysbegeerte of 'n wysbegeerte wat uitgewerk is in 'n lewensbeskouing, oorvleuel natuurlik op punte. So gesien gaan dit hier dus om algemene uitgangspunte wat ten grondslag van die hele lewe moet lê - of jy nou teologies besig is of nie.

\section{Uitgangspunte reformatories}

Van Wyk slaan die spyker op die kop as hy verwys na 'n aantal bekende Bybelse of Christelike temas wat vir die onderwys in die algemeen van groot belang is.

Die hele lewe - wat 'n koninkryksbewuste Christen betref - moet natuurlik voor die aangesig van God wees (Van der Walt, 1990:6). Dit sluit die onderwys in. Van Wyk se opmerking dat die Christen geen tweeslagtigheid in of tweedeling van die lewe mag erken nie, slaan die spyker op die kop. Hy maak hier 'n fundamentele uitspraak waaroor daar "onder ons" geen verskil van mening kan wees nie (vgl. ook Van Wyk, 1983). Die enigste probleem op hierdie punt in Van Wyk se betoog - dit kom ook op ander punte voor - is sy onvermoë om dit vir die skool en die onderwyser in "praktiese" skoolvoorbeelde om te sit. Hy skryf heerlik bevatlik in populêre teologiese taal, maar bly ' $n$ bietjie ver van elke dag se skoolbelewenis af.

Van Wyk se skets van die verligtende werk wat die Heilige Gees deur die Woord in ons doen, verskaf 'n helder en duidelike algemene tipering van die verhouding tussen die Bybel en die 
wetenskap. Dit gee duidelikheid oor die uitdrukking "In U lig" van Psalm 36:10. Minder duidelik onder hierdie subtema is die kort slotparagraaf oor die bekende antitese. Hier erken Van Wyk in een sin die realiteit hiervan, maar in die volgende sin sê hy negatief, feitlik onverstaanbaar én ongemotiveerd dat 'n mens van die antitese alleen nie kan leef nie. Die raakvat van die antitese is een van die winspunte van die Reformatoriese Wysbegeerte en eksponente op nie-wysgerige reformatoriese terreine het ook grondig en verantwoord daarvan kennis geneem (vgl. Brillenburg Wurth, 1940). 'n Meer uitvoerige aanpak hiervan deur Van Wyk kon tot groter duidelikheid van hierdie ter sake, aktuele saak bygedra het.

Van Wyk se uiteensetting van die Christelike akademie as een van die tekens van God se koninkryk, is verhelderend. Aan die einde van hierdie onderafdeling roer hy kerk en skool egter ietwat deurmekaar as hy stel dat die koningskap van Christus buite die kerk slegs met oortuiging bely kan word waar almal Christene is. Die skool is nie, soos die kerk, 'n belydende gemeenskap nie, sodat Christelike onderwys as 'n waarheidsmoment - Van Wyk se term ook by nie-gelowiges aangetref kan word. Aan die ander kant stuit sy argument hier by implikasie op Kuyper se denklyn dat die kerk in sy verlengde - die kerk as "organisme" soos, ironies genoeg, afgewys deur Van Wyk - hier net met meer oortuiging en egtheid kan handel. Heyns (1977:198 e.v.) handhaaf ook nie die onderskeid tussen die kerk as instituut en as organisme nie, maar verklaar op hierdie punt ad rem: "Vir die kerk as instituut geld die notae ecclesiae maar vir die kerk as organisme nie - daar gaan dit alleen om die Christelike lewe in die algemeen. Dit lei ... tot 'n konfessionele uitholling van die kerk. Hoe kan die konfessionele karakter van die institutêre kerk op die kerk as organisme oorgedra word? En hoe kan dit daar gehandhaaf word?"

Van Wyk raak twee baie aktuele temas uit die een-en-twintigste eeu aan as hy beweer dat onderwys ook tot die welsyn van die samelewing en die ekologie waarbinne dit funksioneer, moet wees. Laasgenoemde tema was by die laaste byeenkoms van die Wêreldbond van Gereformeerde Kerke in 2004 in Accra in Ghana een van die groot sake op die agenda. Van Wyk se pleidooi vir 'n eties-sosiale gedragskode vir Suid-Afrikaners verdien beslis aandag en verdere besinning. Hy is reg as hy aanvoer dat so 'n kode tot inspirasie vir die jeug kan dien.

Die laaste twee temas of uitgangspunte wat Van Wyk aanwys, kan net so onderskryf word. Dit bevat eerstens die wyd aanvaarde 
Christelike uitgangspunt dat onderwys tot volwassenheid en gebalanseerde persoonlikheidsontsluiting moet lei (vgl. PU vir $\mathrm{CHO}$, 1988:205 e.v.). Die tweede saak benadruk die oortuiging dat Christelike onderwys ook aan aanvaarde akademiese standaarde moet beantwoord. Die aktualiteit van laasgenoemde word onderstreep deur diegene wat oningelig verklaar dat 'n wetenskap wat aan "waarde-oordele" gebonde is, nie op standaard kan wees nie. So 'n standpunt word deur twee oorwegings gedruk: die eerste is die meer moderne "ontdekking" dat geen wetenskapsbeoefening neutraal is of kan wees nie. Die tweede is dat 'n raak insig in die werklikheid as skepping van God eerder standaarde verhoog as verlaag.

Om mee af te sluit en vir sy "vreemdheid" aan die praktiese onderwyssituasie in Suid-Afrika te vergoed, kom Van Wyk met 'n lysie probleme en uitdagings in die praktyk wat hulle oorsprong by die Konvent van Reformatoriese Kerke se byeenkoms in Maart 2006 vind. Hy eindig met 'n opmerking dat die huidige skool- en naskoolse stelsel in Suid-Afrika hom tans in 'n stroomversnelling bevind wat daarop gemik is om voortgaande neutralisering te weeg te bring. Hyself pleit egter dat die owerheid die insig aan die dag sal lê om differensiasie ten opsigte van die lewensbeskoulike "rigting" by onderwysinstellings toe te pas en dat staatsubsidies slegs standaarde in ag sal neem. Soos by Augustinus, kan 'n nieChristelike opvoeding ook 'n bydrae tot 'n kind se opvoeding lewer.

\section{Eindopmerkings}

Van Wyk se bydrae verteenwoordig onteenseglik 'n winspunt "in 'n tyd soos hierdie". Sy rustige uiteensettings in maklik volgbare terme dra verder daartoe by. Dit is ook aanvaarbaar dat hy vanuit 'n nieopvoedkundige hoek as 'n "buite-belangstellende" na algemene Christelike uitgangspunte soek wat ook vir die onderwys en die onderwyser geld. Dit illustreer dat die teologie of 'n algemene Christelike lewensbeskouing nie werklikheidsvreemd is nie.

Omdat hy in elke geval by 'n etiese gedragkode vir Suid-Afrikaners uitkom, is dit 'n vraag waarom hy nie by God se allesdekkende kosmiese wet en die allesomvattende dekaloog in die Bybel ook uitkom nie. Vanuit 'n gesonde gereformeerde benadering is die dekaloog en gebed die twee aspekte waarin ons gehoorsaam dankie sê vir God se allesomvattende verlossing. Anders gestel: as die Heidelbergse Kategismus hom nou soos van Wyk oor die koninkryk van God moes verantwoord, sou die bevinding waarskynlik wees dat die Here God deur ons gebede en 
gehoorsaamheid aan sy wet, in ons heers. Daarom sou die grondmotiewe vir die regte leefstyl soos die Kategismus se sonde, verlossing en dankbaarheid, ook toepaslik wees. Hierdie grondmotiewe sou vanuit die Christelike Wysbegeerte ook aangevul kon word met die drie motiewe van skepping, sondeval en verlossing.

Gereformeerdes is nie antinomiste nie. Een van die trekke van goeie onderwys is juis dat dit afgestem is op duidelike standaarde en helderheid oor gedrag. Wat meer is, die wet kan juis die kanale bied waardeur van Wyk se positiewe temas deur middel van die onderwys konkrete gestalte kry.

\section{Geraadpleegde bronne}

BOTHA, M.E. 1982. Christelik-nasionaal: outentieke, ideologiese of gesekulariseerde nasionalisme? Potchefstroom: Instituut vir Reformatoriese Studie.

BRILLENBURG WURTH, G. 1940. De anthitese in dezen tijd. Kampen: Kok.

HEYNS, J.A. 1977. Die kerk. Pretoria: NG Kerkboekhandel.

PU vir CHO. 1988. Christelike perspektiewe op opvoeding en onderwys. Pretoria: SACUM.

STRAUSS, H.J. 1969. Christelik-nasionaal en CNO. Bloemfontein: SACUM.

VAN DER WALT, B.J. 1990. Om mens te wees. Potchefstroom: Instituut vir Reformatoriese Studie.

VAN WYK, J.H. 1983. Calvyn oor die Christelike lewe. Pretoria: NG Kerkboekhandel. 
Respons op J.H. van Wyk se Reformasie en onderwys(-ers): enkele teologiese ... 